\title{
Physico-Chemical Properties and Biocompatibility of Thermosensitive Chitosan Lactate and Chitosan Chloride Hydrogels Developed for Tissue Engineering Application
}

\author{
Katarzyna Pieklarz ${ }^{1, *}$, Grzegorz Galita ${ }^{2}$, Michał Tylman ${ }^{3}$, Waldemar Maniukiewicz ${ }^{4}{ }^{\oplus}$, Ewa Kucharska ${ }^{5}$, \\ Ireneusz Majsterek ${ }^{2}$ and Zofia Modrzejewska ${ }^{1}$
}

1 Department of Environmental Engineering, Faculty of Process and Environmental Engineering, Lodz University of Technology, Wolczanska 213 Street, 90-924 Lodz, Poland; zofia.modrzejewska@p.lodz.pl

2 Department of Clinical Chemistry and Biochemistry, Medical University of Lodz, Narutowicza 60 Street, 90-136 Lodz, Poland; grzegorz.galita@umed.lodz.pl (G.G.); ireneusz.majsterek@umed.lodz.pl (I.M.)

3 PGE Gornictwo i Energetyka Konwencjonalna S.A., Weglowa 5 Street, 97-400 Belchatow, Poland; michal.tylman1@gmail.com

4 Institute of General and Ecological Chemistry, Faculty of Chemistry, Lodz University of Technology, Zeromskiego 116 Street, 90-924 Lodz, Poland; waldemar.maniukiewicz@p.lodz.pl

check for

updates

Citation: Pieklarz, K.; Galita, G.;

Tylman, M.; Maniukiewicz, W.;

Kucharska, E.; Majsterek, I.;

Modrzejewska, Z. Physico-Chemical

Properties and Biocompatibility of

Thermosensitive Chitosan Lactate

and Chitosan Chloride Hydrogels

Developed for Tissue Engineering

Application. J. Funct. Biomater. 2021,

12, 37. https://doi.org/10.3390/

jfb12020037

Academic Editors: John G. Hardy,

Elzbieta Pamula, Timothy

E.L. Douglas, Marloes Peeters and

Giuseppe Perale

Received: 21 April 2021

Accepted: 17 May 2021

Published: 20 May 2021

Publisher's Note: MDPI stays neutral with regard to jurisdictional claims in published maps and institutional affiliations.

Copyright: (c) 2021 by the authors. Licensee MDPI, Basel, Switzerland. This article is an open access article distributed under the terms and conditions of the Creative Commons Attribution (CC BY) license (https:// creativecommons.org/licenses/by/ $4.0 /)$.
5 Department of Gerontology, Geriatrics and Social Work, Jesuit University Ignatianum in Krakow, Kopernika 26 Street, 31-501 Krakow, Poland; ewa.kucharska@ignatianum.edu.pl

* Correspondence: katarzyna.pieklarz@dokt.p.lodz.pl

Abstract: Recently, the modification of the initial structure of biopolymers, mainly chitosan, has been gaining importance with a view to obtain functional forms with increased practicality and specific properties enabling their use in tissue engineering. Therefore, in this article, the properties (structural and biological) of thermosensitive hydrogels obtained from chitosan lactate/chloride and two types of crosslinking agents ( $\beta$-glycerol phosphate disodium salt pentahydrate and uridine $5^{\prime}$-monophosphate disodium salt) are discussed. The aim of the research is to identify changes in the structure of the biomaterials during conditioning in water. Structural investigations were carried out by FTIR spectroscopy. The crystallinity of gels was determined by X-ray diffraction analysis. The biocompatibility (evaluation of cytotoxicity and genotoxicity) of chitosan hydrogels was investigated by contact with human colon adenocarcinoma cell line for $48 \mathrm{~h}$. The cytotoxicity was verified based on the colorimetric resazurin assay, and the genotoxicity was checked by the comet assay (percentage of DNA in the comet tail). The conducted research showed that the analyzed types of chitosan hydrogels are non-cytotoxic and non-genotoxic materials. The good biocompatibility of chitosan hydrogels surfaces makes them interesting scaffolds with clinical potential in tissue regeneration engineering.

Keywords: tissue engineering; natural polymer; chitosan; thermosensitive hydrogel; structural properties; cytotoxicity; genotoxicity

\section{Introduction}

For several years, the research undertaken in the field of tissue engineering, which is an innovative but intensively developing discipline of science based on the issues related to the fields of materials science, biology, biotechnology, chemistry, and biochemistry, has been gaining importance [1-3]. This is because the standard methods of treating damaged tissues, such as pharmacotherapy and transplant techniques, are often of limited effectiveness. Therefore, the solutions offered by tissue engineering constitute an alternative. They do not require the use of materials with a low degree of biocompatibility and postpone the need for arthroplasty, allowing the patient to return to full mobility and to their everyday activities $[4,5]$.

The essence of tissue engineering is to create biomaterials that can replace or regenerate damaged tissue and restore its basic function. The regeneration process takes place in 
several stages. The first step is the biopsy of a piece of tissue that is processed to isolate the necessary cells from the extracellular matrix. The next component of the process is to multiply the cells (in vitro) and seed them on a scaffold, and then cultivate them in a bioreactor under optimal environmental conditions, culture medium and growth factors. The final step is the implementation (in vivo) of the obtained scaffold with multiplied cells into the patient's body. It is also important that the material for the scaffold is slowly degraded and resorbed [6-9].

Currently, the manufacture of new materials for scaffolds is a trend in global scientific research. Hydrogels, which are three-dimensional hydrophilic matrices made of crosslinked homopolymers, copolymers or macromers, occupy a special position [10]. Given the nature of crosslinks, there are physical and chemical hydrogels. The first type of gels is created by various reversible links, for example van der Waals interactions, hydrogen bonds or electrostatic interactions. These interactions can be induced and reversed depending on the $\mathrm{pH}$ or the temperature making them especially useful in biomedicine. In turn, the chemical systems are formed by irreversible covalent links and compared with physically crosslinked gels are more stable under physiological conditions and have better mechanical properties [11-13].

Due to the relatively high water content, softness and plasticity, hydrogels exhibit similar physical properties to living tissues. These biomaterials, apart from being used in tissue engineering, are an excellent material for obtaining immunoisolation barriers for microencapsulation technology and dressings for the treatment of skin damage and burns. Additionally, they are applied as smart carriers in controlled drug delivery systems. This solution ensures a safe and effective therapy. Unlike conventional drug delivery systems in which the substance is released immediately after entering the body, the drug takes effect after a certain period and is dosed evenly. Moreover, hydrogels are used as gene carriers and as integral components of microdevices such as biosensors [14-19].

An extremely interesting form of hydrogels are temperature-sensitive systems, which can undergo a phase transition at the human body temperature. In general, they consist of hydrophobic and hydrophilic components, and the thermal response is caused by the equilibrium between the above parts of the polymer monomer [20].

The main advantage of thermosensitive hydrogels is the possibility of their noninvasive introduction into the pathologically affected area by injection, which avoids first-pass metabolism. In addition, these biomaterials can assume a shape that perfectly matches the tissue damage. This removes the need for a surgical operation, reduces the adhesion problems of cells and bioactive substances, and eliminates the difficulties associated with their even dispersion in the structure. This is due to the possibility of introducing cells and therapeutic agents into the solution before administration - in situ [20-22].

Hydrogels with thermosensitive properties are mainly obtained from poly (Nisopropylacrylamide)-based (PNIPAAM) copolymers, poly (ethylene glycol)/biodegradable polyester copolymers, chitosan and its derivatives [23,24].

Among the above polymers, chitosan (Figure 1), a polysaccharide resulting from the alkaline deacetylation of chitin, is a particularly promising material for scaffolds. This biopolymer exhibits many unique biological, physiological, and pharmacological properties: nontoxicity, biocompatibility with living tissues and biodegradability. The bioactivity of chitosan is also noteworthy, including acceleration of the wound healing process, increased immunity, hemostatic activity, induction of a biological response, bactericidal and fungicidal activity [25-28]. 


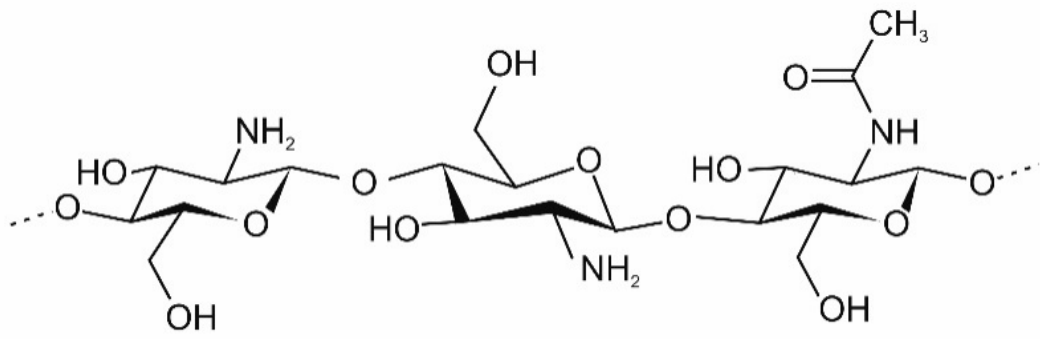

Figure 1. Structure of chitosan.

Chitosan is degraded in the human body by several physiological enzymes (lysozyme, di-N-acetylchitobiase, $\mathrm{N}$-acetyl-beta-d glucosaminidase and chitiotriosidase etc.), and the process of its biodegradation causes release of nontoxic oligosaccharides [29-32].

However, it should be borne in mind that the biocompatibility of this material can be influenced many factors, for example the degree of deacetylation, particle size, concentration, or route of administration [33]. There are also studies pointing to the potential of chitosan and its degradation products to activate human macrophages and lymphocyte proliferation without symptoms of inflammation [32,34].

The current legislation states that each new material intended to be used in the biomedical field must be subject to extensive research aimed at assessing its cytotoxicity before referring it to clinical trials. In addition, each modification of a previously assessed solution may affect its potential cytotoxic activity.

In this paper, hydrogels with thermosensitive properties are shown. These systems were formed from chitosan lactate and chitosan chloride solutions with the use of $\beta$-glycerol phosphate disodium salt pentahydrate $(\beta-\mathrm{GP})$ (Figure 2 ) and uridine $5^{\prime}$-monophosphate disodium salt (UMP) (Figure 3 ) as the crosslinking agents.<smiles>O=P(O[Na])(O[Na])OC(CO)CO</smiles>

Figure 2. Structure of $\beta$-glycerol phosphate disodium salt pentahydrate.

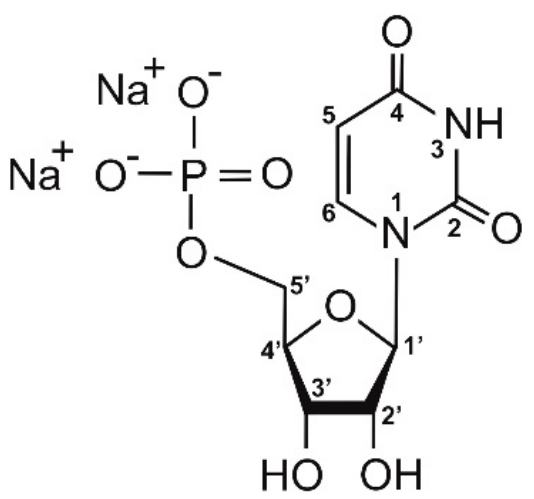

Figure 3. Structure of uridine $5^{\prime}$-monophosphate disodium salt.

Uridine $5^{\prime}$-monophosphate disodium salt is an organic chemical compound, a nucleotide that is a major component of ribonucleic acid. This neuroactive molecule plays an important function in the pyrimidine metabolism of the brain, furnishes nervous tissue with the pyrimidine ring and takes part in the metabolic pathways. In addition, UMP acts as a signaling molecule in the central nervous system and participates in the control of 
physiological and pathophysiological brain functions. This nucleotide can be used in the treatment of neurodegenerative diseases and polyneuropathy and in the therapy of the myelin sheath lesion $[35,36]$.

The literature suggests that chitosan hydrogels formed at $37^{\circ} \mathrm{C}$ are most obtained by the addition of $\beta$-glycerol phosphate disodium salt pentahydrate [37-41].

However, there is no information on the preparation of the thermo-gelling systems with the participation of uridine $5^{\prime}$-monophosphate disodium salt. Only the production of biomaterials using derivatives of uridine (oUrd) and uridine monophosphate (oUMP) in combination with glutaraldehyde (AG) has been discussed, but these systems did not show phase transition under the influence of the temperature [42].

A review of the available publications presents that the hydrogels with thermosensitive properties formed by the presence of uridine $5^{\prime}$-monophosphate disodium salt is only found in our previous article [43]. The study was carried out to determine the structural properties of pure hydrogels, prepared from chitosan lactate and chitosan chloride, based on FTIR spectra analysis and morphology of these biomaterials evaluated by scanning electron microscope (SEM). In addition, to assess the state of water in the structure of hydrogels, thermal analysis was performed using a differential scanning calorimetry (DSC).

In turn, this publication is focused on the determination of changes in the structure of the gels containing $\beta$-GP and UMP due to conditioning in water, which is particularly important when considering the possibility of using hydrogels, for example as scaffolds in tissue engineering or carriers for controlled drug release.

The obtained biomaterials were characterized by Fourier transform infrared spectroscopy (FTIR) and X-ray diffraction (XRD) studies.

In turn, the biological research included the evaluation of the cytotoxicity and genotoxicity of the developed chitosan hydrogels using human colon adenocarcinoma cell line (HT-29 cell line).

\section{Materials and Methods}

\subsection{Materials of Hydrogels}

Chitosan (CH) product no. 50494-100GF, lactic acid (LA) product no. L6661-100ML, hydrochloric acid (HCL) product no. H1758-100ML, the crosslinking agents: $\beta$-glycerol phosphate disodium salt pentahydrate ( $\beta$-GP) product no. 50020-100G and uridine $5^{\prime}$ monophosphate disodium salt (UMP) product no. U6375-10G were purchased from SigmaAldrich (Poznan, Poland). Deionized water treated by a water purification system (Elga Purelab, High Wycombe, UK) was used in the preparation of chitosan hydrogels and their conditioning. All chemical reagents were of analytical grade and were used without further purification.

\subsection{Preparation of Solutions and Hydrogels Manufacture}

Thermosensitive chitosan hydrogels were prepared by physical blending. Firstly, $\mathrm{CH}$ $(0.4 \mathrm{~g})$ was dissolved in $16 \mathrm{~mL} \mathrm{LA}$ or HCL $(0.1 \mathrm{~mol} / \mathrm{L})$. The solutions were stirred (at slow rotations) until complete dissolution and left at room temperature for $24 \mathrm{~h}$. Then, solutions of the crosslinking agents $\left(2 \mathrm{~g} \beta\right.$-GP was dissolved in $2 \mathrm{~mL}$ deionized water at $4{ }^{\circ} \mathrm{C}$, while $2 \mathrm{~g}$ UMP was dissolved in $2.5 \mathrm{~mL}$ deionized water at $4{ }^{\circ} \mathrm{C}$ ) were added drop by drop into the chitosan salts solutions. Each sample was mixed for $20 \mathrm{~min}$ and stored at $4{ }^{\circ} \mathrm{C}$ for about $1 \mathrm{~h}$. The prepared formulations were homogeneous solutions, which were subsequently incubated at $37^{\circ} \mathrm{C}$ to complete their gelation. Due to the fact that the obtained hydrogels looked the same, only a photograph of the $\mathrm{CH}$ /LA/UMP system is shown in Figure 4 . 


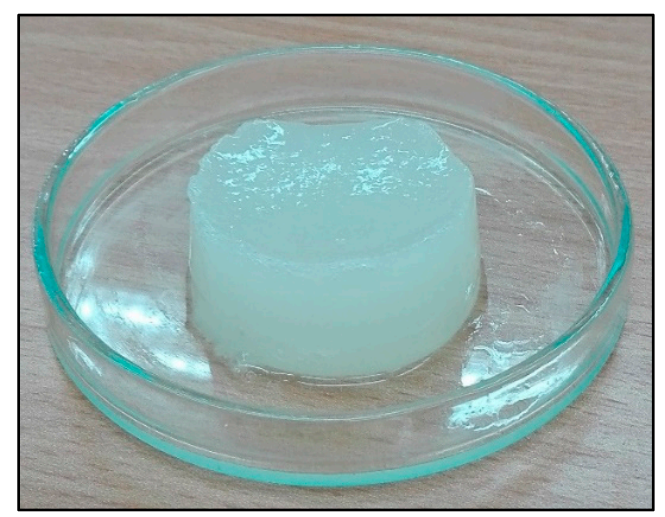

Figure 4. Thermosensitive chitosan hydrogel (the $\mathrm{CH} / \mathrm{LA} / \mathrm{UMP}$ system).

\subsection{In Vitro Conditioning}

The prepared thermosensitive chitosan hydrogels were subjected to the in vitro release process carried out under static conditions without mixing. The release process of $\beta$-GP and UMP was studied in $100 \mathrm{~mL}$ deionized water, maintaining a constant at $37^{\circ} \mathrm{C}$.

\subsection{Physico-Chemical Studies}

The structural properties of chitosan gels before and after conditioning in water for $1,2,4,6,8,24,48$ and $72 \mathrm{~h}$ were analyzed. Each of the samples for analysis were frozen at $-20^{\circ} \mathrm{C}$ and then lyophilized under the pressure of $0.63 \mathrm{mbar}$ and the temperature of $-25^{\circ} \mathrm{C}$ for about $48 \mathrm{~h}$ using the Martin Christ Freeze Dryer ALPHA 2-4.

\subsubsection{Fourier Transform Infrared Spectroscopy}

Fourier transform infrared (FTIR) spectra of the lyophilized chitosan hydrogels were characterized using a Nicolet ${ }^{\mathrm{TM}}$ iS50 FT-IR apparatus equipped with a monolithic diamond ATR crystal (Thermo Fisher Scientific Inc., Madison, WI, USA). All spectra were recorded with 100 scans at a $4.0 \mathrm{~cm}^{-1}$ resolution in the range of wavenumbers $4000-500 \mathrm{~cm}^{-1}$.

\subsubsection{X-ray Diffraction}

The crystalline structure of obtained hydrogels was accessed by the room temperature powder X-ray diffraction technique. The study was performed in the PANanalytical $X^{\prime}$ Pert Pro MPD diffractometer in the Bragg-Brentano reflection geometry with $(\mathrm{CuK} \alpha)$ radiation from a sealed tube (Malvern Panalytical Ltd., Royston, UK). The Cu radiation was generated at $30 \mathrm{~mA}$ and $40 \mathrm{kV}$. The apparatus operated in the range of $2 \theta=3-40^{\circ}$, with a step size of $0.0167^{\circ}$, and the measuring time was $20 \mathrm{~s} / \mathrm{step}$.

\subsection{Biological Studies}

\subsubsection{Cell Culture}

The analysis of biological properties of the chitosan biomaterials was carried out on the commercially available human colon adenocarcinoma cell line (HT-29 cell line) purchased from the American Type Culture Collection (ATCC; Manassas, VA, USA). The cells were cultured in McCoy's 5A medium (Sigma-Aldrich Corp., St. Louis, MO, USA) supplemented with $10 \%(v / v)$ fetal bovine serum (FBS; Sigma-Aldrich Corp., St. Louis, MO, USA), 100 units $/ \mathrm{mL}$ penicillin and $100 \mu \mathrm{g} / \mathrm{mL}$ streptomycin (both from GIBCO-BRL, Life Technologies Ltd., Paisley, Scotland). After exposure to accutase solution, the cells were passaged at $85-95 \%$ confluency.

\subsubsection{Preparation of $\mathrm{CH}$ Solutions for Cytotoxicity and Genotoxicity Studies}

Sterile $\mathrm{CH}$ formulations for the biological studies were prepared under aseptic conditions in a vertical laminar airflow cabinet equipped with UV sterilization and HEPA filters (PCR Workstation by Labcaire Systems Ltd., Clevedon, UK). 


\subsubsection{Cytotoxicity Analysis}

To evaluate the cytotoxic effect of the hydrogels on the studied cell line, the colorimetric resazurin assay, In Vitro Toxicology Assay Kit, Resazurin based (Sigma-Aldrich Corp., St. Louis, MO, USA) was performed. All analyses were carried out in triplicate with similar results. HT-29 cells were seeded in 12-well plates $\left(2 \times 10^{5}\right.$ cells/well $)$ and cultured in $1 \mathrm{~mL}$ of complete McCoy's 5A medium for $24 \mathrm{~h}$. The cells suspended in $1 \mathrm{~mL}$ of complete culture medium were used as a negative control, whereas cells treated with $100 \%$ DMSO (Sigma-Aldrich Corp., St. Louis, MO, USA) as a positive control. After cells' adhesion, the cells were incubated with small pieces of hydrogels (diameter: $5 \mathrm{~mm}$ ) for $48 \mathrm{~h}$. Following incubation, the well contents were removed, and the cells were rinsed twice with $1 \mathrm{X}$ DPBS. Subsequently, $100 \mu \mathrm{L}$ of the resazurin solution was added to each well, and the cells were incubated for $2 \mathrm{~h}$. Absorbance was measured at a wavelength of $600 \mathrm{~nm}$ and a reference wavelength of $690 \mathrm{~nm}$ using Synergy HT (BioTek) spectrophotometer.

\subsubsection{Genotoxicity Assessment}

The genotoxicity of the analyzed hydrogels was estimated using the alkaline version of the comet assay. HT-29 cells were seeded in 12-well plates $\left(2 \times 10^{5}\right.$ cells/well) and cultured in $1 \mathrm{~mL}$ of complete McCoy's 5A medium for $24 \mathrm{~h}$. The cells suspended in $1 \mathrm{~mL}$ of complete culture medium were used as a negative control, whereas cells treated with $10 \%$ DMSO as a positive control. After cells' adhesion, the cells were incubated with small pieces of hydrogels (diameter: $5 \mathrm{~mm}$ ) for $48 \mathrm{~h}$. Following incubation, the well contents were removed, and $0.2 \mathrm{~mL}$ of accutase/well was added to harvest the cells. The harvested cells were centrifuged. Cell suspension in 0.37\% LMP agarose (Sigma-Aldrich Corp., St. Louis, $\mathrm{MO}$, USA) was placed on microscope slides, which were previously coated with NMP agarose (Sigma-Aldrich Corp., St. Louis, MO, USA). Subsequently, the preparations were incubated in lysis buffer (2.5-M NaCl, 10-mM Tris, 100-mM EDTA, $\mathrm{pH} 10)$ with the addition of $1 \%$ TritonX-100 (Sigma-Aldrich Corp., St. Louis, MO, USA) at $4{ }^{\circ} \mathrm{C}$ for $1 \mathrm{~h}$. Following the lysis, the preparations were incubated in development buffer ( $300 \mathrm{mM} \mathrm{NaOH}, 1 \mathrm{mM}$ EDTA) at $4{ }^{\circ} \mathrm{C}$ for $20 \mathrm{~min}$, followed by electrophoresis ( $\left.17 \mathrm{~V}, 32 \mathrm{~mA}, 20 \mathrm{~min}\right)$ at $4{ }^{\circ} \mathrm{C}$ in an electrophoretic buffer ( $30 \mathrm{mM} \mathrm{NaOH}, 1 \mathrm{mM}$ EDTA). Then, the slides were rinsed with distilled water and left to dry completely. The obtained preparations were stained with a DAPI fluorescent dye and examined under a fluorescent microscope to assess the level of DNA damage.

\subsubsection{Statistical Analysis}

Statistical analysis was carried out using a nonparametric technique: the MannWhitney test in statistical program Sigma Plot (Systat Software, Inc.). Each of the analyses in individual experiments were based on the results of three independent tests. Significant statistical differences were presented as follows: ${ }^{*} p<0.05,{ }^{* *} p<0.01$, ${ }^{* * *} p<0.001$ versus the negative control.

\section{Results and Discussion}

\subsection{Fourier Transform Infrared (FTIR) Spectra}

To identify individual functional groups, FTIR spectra of chitosan hydrogels were made. The structure of the biomaterials formed with the use of $\beta$-glycerol phosphate disodium salt pentahydrate and uridine $5^{\prime}$-monophosphate disodium salt was compared.

The results in Figures 5 and 6 show the spectra of chitosan lactate hydrogels (the $\mathrm{CH} / \mathrm{LA} / \beta$-GP system) and chitosan chloride (the $\mathrm{CH} / \mathrm{HCL} / \beta$-GP system) with $\beta$-glycerol phosphate disodium salt pentahydrate after different times of conditioning in water and, for comparison, the spectra of the gels before conditioning $(0 \mathrm{~min})$ and the spectrum of chitosan $(\mathrm{CH})$ powder. 


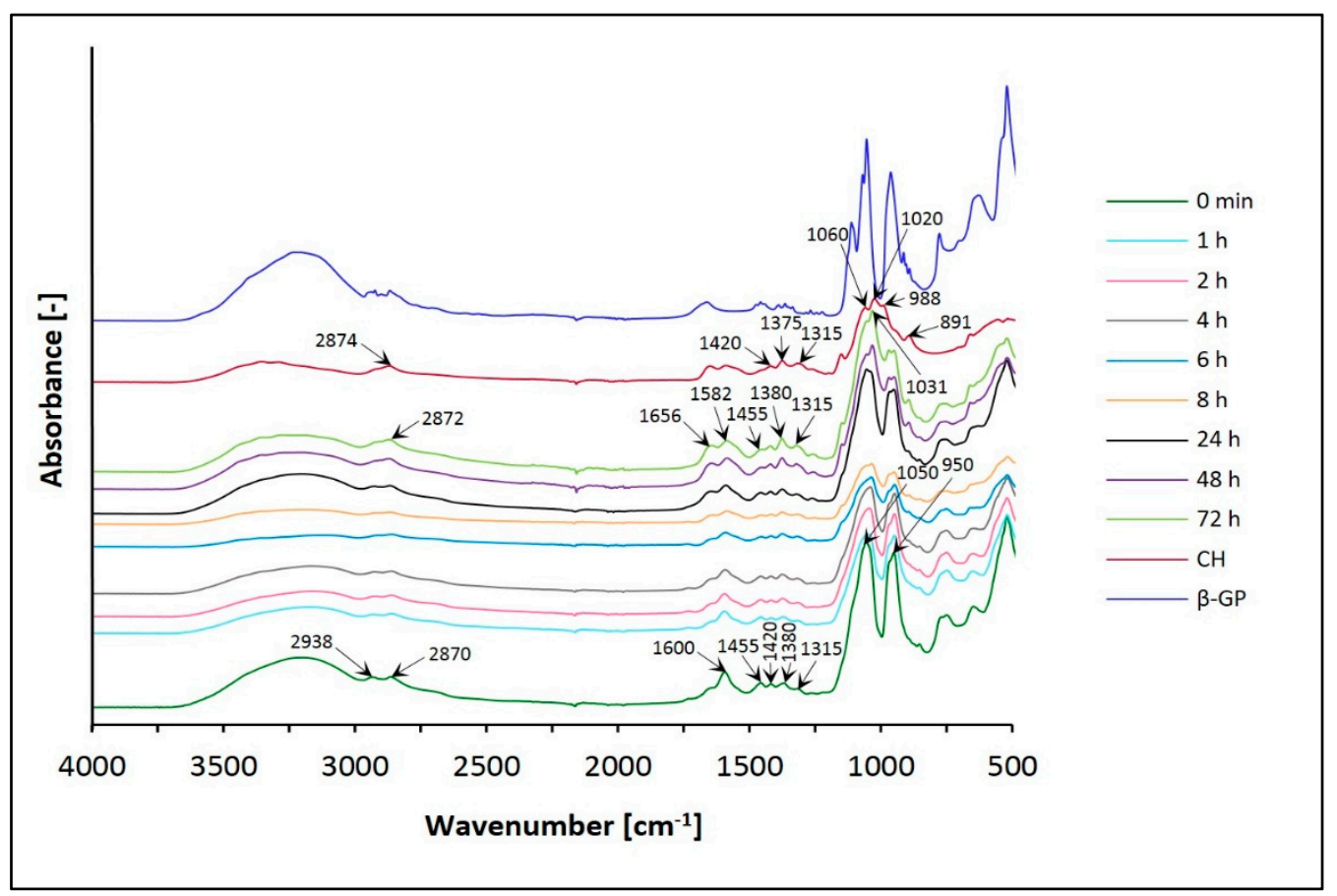

Figure 5. FTIR spectra of the $\mathrm{CH} / \mathrm{LA} / \beta-\mathrm{GP}$ system conditioned in water.

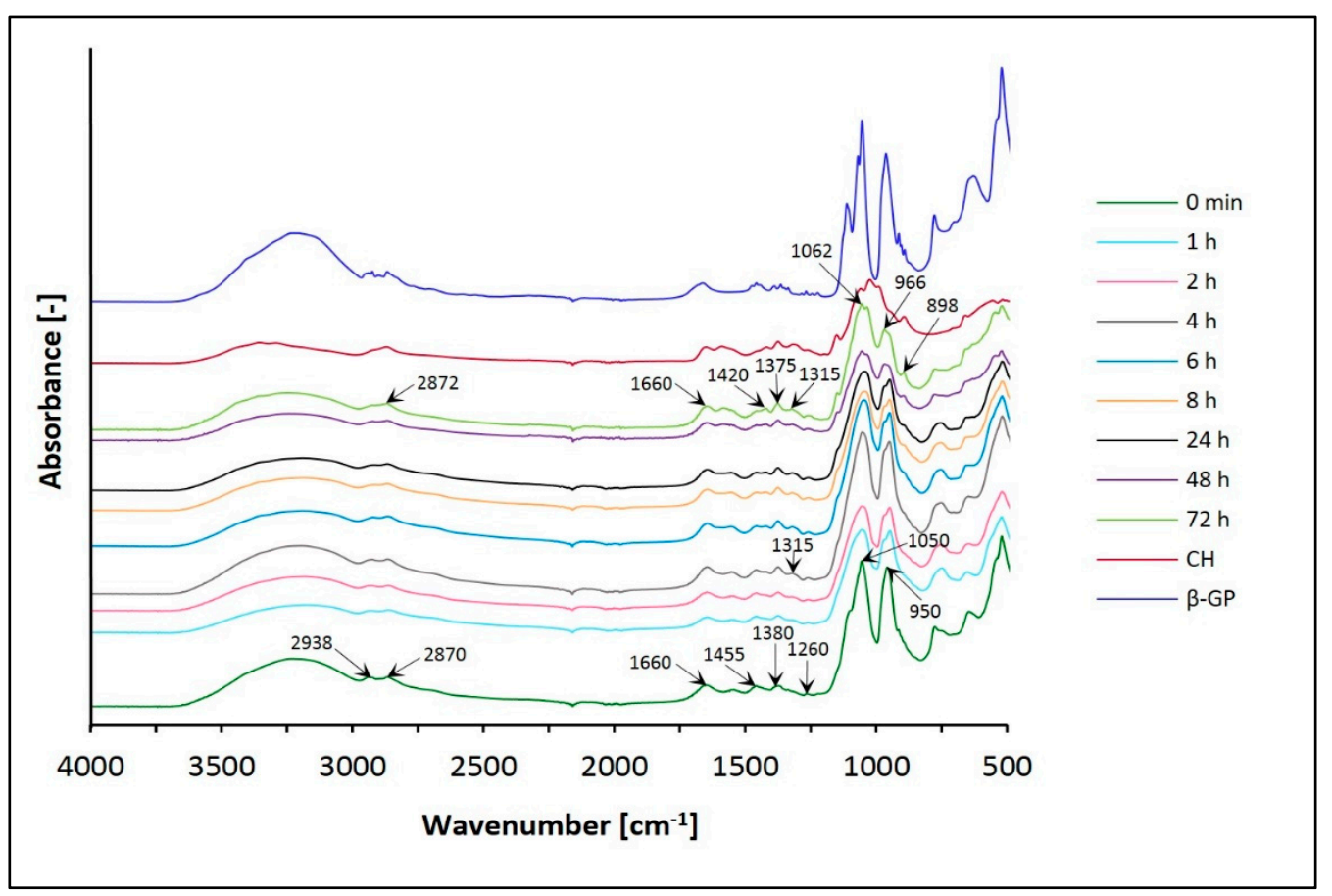

Figure 6. FTIR spectra of the $\mathrm{CH} / \mathrm{HCL} / \beta-\mathrm{GP}$ system conditioned in water.

On the other hand, Figures 7 and 8 present the spectra of chitosan lactate hydrogels (the $\mathrm{CH} / \mathrm{LA} / \mathrm{UMP}$ system) and chitosan chloride (the $\mathrm{CH} / \mathrm{HCL} / \mathrm{UMP}$ system) with uridine $5^{\prime}$-monophosphate disodium salt. 


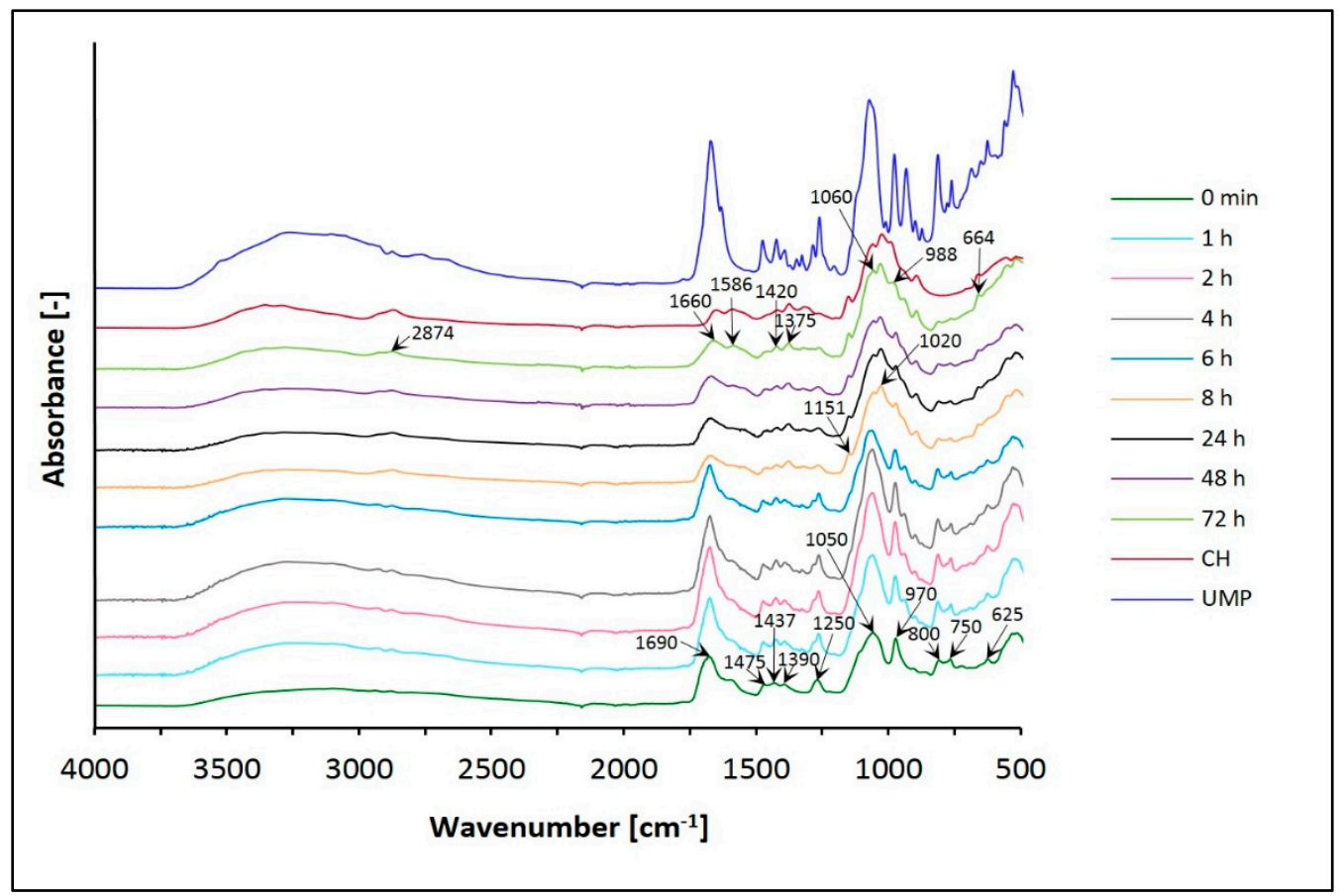

Figure 7. FTIR spectra of the $\mathrm{CH} / \mathrm{LA} / \mathrm{UMP}$ system conditioned in water.

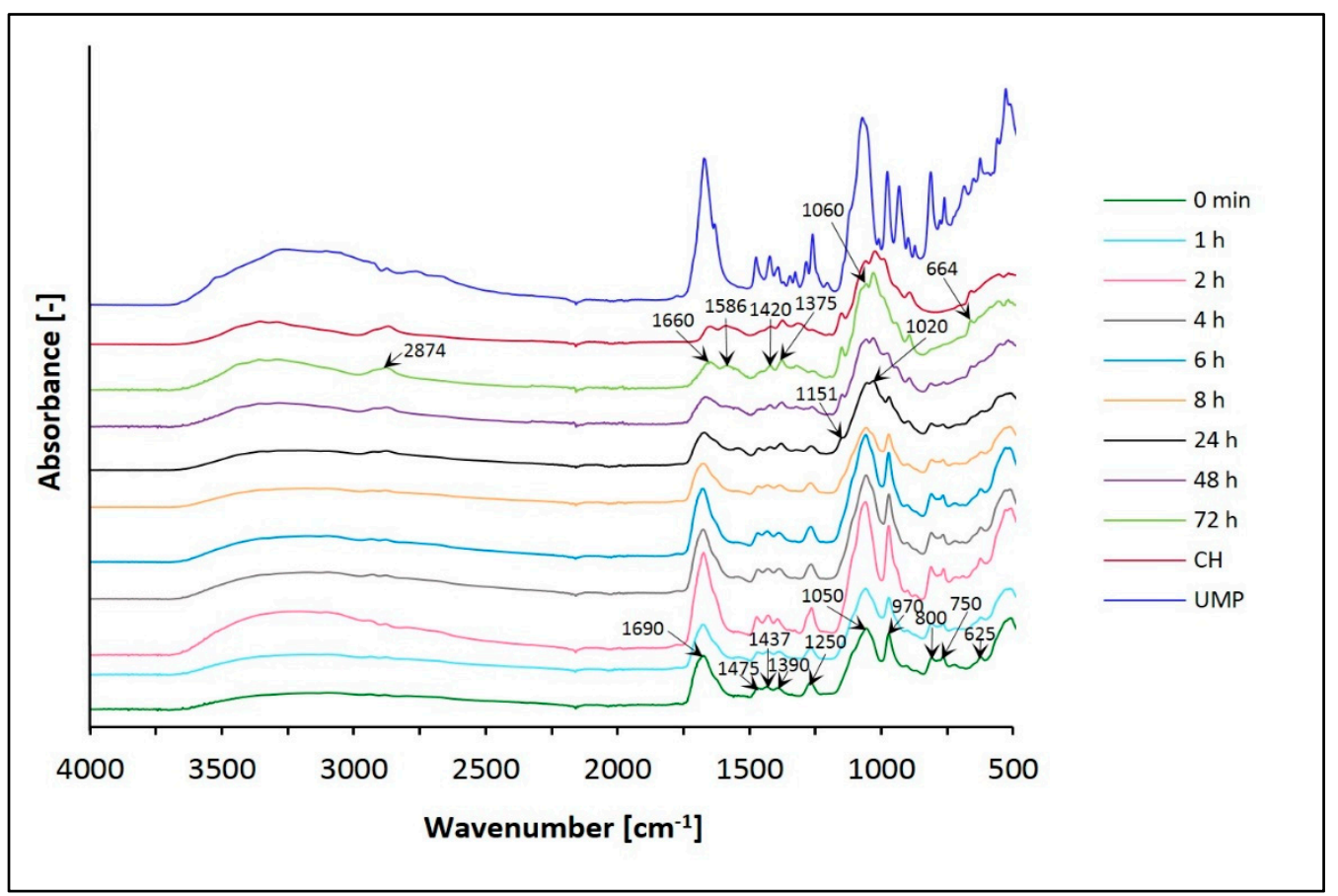

Figure 8. FTIR spectra of the $\mathrm{CH} / \mathrm{HCL} / \mathrm{UMP}$ system conditioned in water.

In the spectra of chitosan hydrogels with $\beta$-glycerol phosphate disodium salt pentahydrate (the $\mathrm{CH} / \mathrm{LA} / \beta$-GP and the $\mathrm{CH} / \mathrm{HCL} / \beta$-GP systems), the broad, asymmetric spectrum in the range of wavenumbers $3600-3100 \mathrm{~cm}^{-1}$ is assigned in all cases before and after conditioning in water. This band corresponds to the $\mathrm{O}-\mathrm{H}$ stretching, indicating intermolecular hydrogen bonding which overlaps the asymmetric stretching vibrations of $\mathrm{NH}_{2}$ groups and the $\mathrm{N}-\mathrm{H}$ stretching vibrations between molecules $\mathrm{N}-\mathrm{H} \ldots \mathrm{O}=\mathrm{C}$ in the same region. For hydrogels before conditioning $(0 \mathrm{~min})$, the band is shifted towards lower 
wavenumbers compared to the spectrum of $\mathrm{CH}$, and after conditioning this band moves to higher frequencies and becomes more symmetric.

In the range of $2950-2850 \mathrm{~cm}^{-1}$, the spectrum of $\mathrm{CH}$ has an asymmetric band at $2874 \mathrm{~cm}^{-1}$, which consists of two overlapping bands representing the $-\mathrm{CH}_{2}$ and $-\mathrm{CH}_{3}$ aliphatic groups, characteristic of the pyranose ring of $\mathrm{CH}$. The spectra of both types of hydrogels $(0 \mathrm{~min})$ are split into two distinct bands at 2938 and $2870 \mathrm{~cm}^{-1}$. In the case of biomaterials conditioned in water, this band is observed at $2872 \mathrm{~cm}^{-1}$ and has a minor shoulder.

Analyzing the frequency range of $1680-1500 \mathrm{~cm}^{-1}$, it is possible to observe characteristic peaks of $\mathrm{CH}$, corresponding to the $\mathrm{C}=\mathrm{O}$ bond in amide group (amide I vibration) and the amide II band coming from $\mathrm{NH}_{2}$, which indicate that this polymer is a partially deacetylated product of chitin. The spectra of the $\mathrm{CH} / \mathrm{LA} / \beta-\mathrm{GP}$ system $(0 \mathrm{~min})$ and hydrogels after conditioning in water for less than $8 \mathrm{~h}$ show one distinct band of $1600 \mathrm{~cm}^{-1}$ with a minor shoulder. Biomaterials conditioned in water for above $8 \mathrm{~h}$ have two bands at 1656 and $1582 \mathrm{~cm}^{-1}$. On the other hand, in the case of the $\mathrm{CH} / \mathrm{HCL} / \beta$-GP systems (before and after conditioning in water), no significant changes are observed.

In the range of wavenumbers $1500-1200 \mathrm{~cm}^{-1}$, the spectrum of $\mathrm{CH}$ has four peaks associated with oscillations characteristic of the $\mathrm{O}-\mathrm{H}$ and $\mathrm{C}-\mathrm{H}$ bending of $\mathrm{CH}_{2}$ groups and representing the $\mathrm{C}-\mathrm{O}$ stretching of the primary alcoholic group $-\mathrm{CH}_{2}-\mathrm{OH}(1420,1375,1315$ and $1260 \mathrm{~cm}^{-1}$ ). For all the $\mathrm{CH} / \mathrm{LA} / \beta-\mathrm{GP}$ system variants (before and after conditioning in water), bands are observed at 1420, 1315 and $1260 \mathrm{~cm}^{-1}$, as in the case of $\mathrm{CH}$. Additionally, a peak appears at $1455 \mathrm{~cm}^{-1}$, and the band at $1375 \mathrm{~cm}^{-1}$ is shifted to $1380 \mathrm{~cm}^{-1}$. In turn, the spectra of the $\mathrm{CH} / \mathrm{HCL} / \beta$-GP systems ( 0 min and conditioned in water for less than $4 \mathrm{~h})$ present three peaks at 1455,1380 and $1260 \mathrm{~cm}^{-1}$. For biomaterials conditioned in water for 4 and more hours, there is an additional band at $1315 \mathrm{~cm}^{-1}$, as in the case of $\mathrm{CH}$. For hydrogels conditioned for 6 to less than $72 \mathrm{~h}$, the spectrum shows five peaks at 1455, $1420,1380,1315$ and $1260 \mathrm{~cm}^{-1}$. After conditioning for $72 \mathrm{~h}$, only bands typical of the $\mathrm{CH}$ molecule are observed.

The spectrum of $\mathrm{CH}$ in the range of $1200-800 \mathrm{~cm}^{-1}$ shows bands at $1151,1060,1020$, 988 and $891 \mathrm{~cm}^{-1}$, characteristic of saccharide structure (oxygen bridge bond (C-O-C) and $\mathrm{CH}_{3} \mathrm{COH}$ groups). Before conditioning in water, the $\mathrm{CH} / \mathrm{LA} / \beta$-GP system does not have the bands typical for a $\mathrm{CH}$ molecule. However, two new bands, at 1050 and $950 \mathrm{~cm}^{-1}$ with a minor shoulder at $980 \mathrm{~cm}^{-1}$, connected with the presence of $\beta$-glycerol phosphate disodium salt pentahydrate appear in this region. The band at $1050 \mathrm{~cm}^{-1}$ indicates the aliphatic $\mathrm{P}-\mathrm{O}-\mathrm{C}$ stretching, the band at $980 \mathrm{~cm}^{-1}$ is characteristic of the $-\mathrm{PO}_{4}{ }^{2-}$ group, whereas the band at $950 \mathrm{~cm}^{-1}$ may indicate the presence of the $-\mathrm{HPO}_{4}^{-}$group. In the case of the $\mathrm{CH} / \mathrm{HCL} / \beta$-GP system $(0 \mathrm{~min})$, a band at $1050 \mathrm{~cm}^{-1}$ with a small arm for the wavenumber $1100 \mathrm{~cm}^{-1}$ and a peak at $950 \mathrm{~cm}^{-1}$ is observed. The spectra for the $\mathrm{CH} / \mathrm{LA} / \beta$-GP systems conditioned in water for more than $24 \mathrm{~h}$ have peaks typical of $\mathrm{CH}$ $\left(1148,1031\right.$ and $\left.894 \mathrm{~cm}^{-1}\right)$. For the $\mathrm{CH} / \mathrm{HCL} / \beta$-GP systems conditioned for longer than $24 \mathrm{~h}$, there are four bands at 1062, 1031, 966 and $898 \mathrm{~cm}^{-1}$. The bands resulting from the presence of phosphorus in the hydrogels structure disappear.

The spectrum of $\mathrm{CH}$ in the range of $800-500 \mathrm{~cm}^{-1}$ has one band at $664 \mathrm{~cm}^{-1}$, which relates to the vibrations of the $\mathrm{O}=\mathrm{C}-\mathrm{N}$ group. For both types of hydrogels, before conditioning in water, there are bands at 750, 650 and $523 \mathrm{~cm}^{-1}$. The band at $750 \mathrm{~cm}^{-1}$ is characteristic of $\beta$-GP (the aliphatic $\mathrm{P}-\mathrm{O}-\mathrm{C}$ stretching). In this frequency range, no significant changes are observed for all samples conditioned in water.

Interpretation of the FTIR spectra was based on previous studies [44-49].

The spectra of hydrogels with UMP vary with time, as do the spectra of systems with $\beta$-GP. Changes, in the broad band range $3600-3000 \mathrm{~cm}^{-1}$ and for the peak around $2850 \mathrm{~cm}^{-1}$ but primarily in the region of $1750-600 \mathrm{~cm}^{-1}$ are observed.

After conditioning in water, the band in the range of wavenumbers $3600-3000 \mathrm{~cm}^{-1}$ moves toward higher frequencies. In the spectrum of $\mathrm{CH}$, two maxima ( 3360 and $3295 \mathrm{~cm}^{-1}$ ) can be observed; in both types of hydrogels, the $\mathrm{O}-\mathrm{H}$ and $\mathrm{N}-\mathrm{H}$ bands overlap. 
Moreover, spectra obtained for both variants of biomaterials conditioned in water show the band at $2874 \mathrm{~cm}^{-1}$, which is typical of the $\mathrm{CH}$ molecule $\left(-\mathrm{CH}_{2}\right.$ and $-\mathrm{CH}_{3}$ aliphatic groups).

Analyzing the frequency range of $1750-600 \mathrm{~cm}^{-1}$, major changes are observed, which is related to the presence of uridine $5^{\prime}$-monophosphate disodium salt in the hydrogels structure.

Before conditioning in water, in the FTIR spectra of the $\mathrm{CH} / \mathrm{LA} / \mathrm{UMP}$ and the $\mathrm{CH} / \mathrm{HCL} / \mathrm{UMP}$ systems, characteristic peaks are detected at wavenumbers: around $1690 \mathrm{~cm}^{-1}\left(\mathrm{C}(2)=\mathrm{O}\right.$ stretching mode), near $1475 \mathrm{~cm}^{-1}$ (in plane deformation mode of $\mathrm{N}(3)-\mathrm{H}$ ), $1437 \mathrm{~cm}^{-1}$ (deformation mode of $\mathrm{O}-\mathrm{H}$ [ribose]), $1390 \mathrm{~cm}^{-1}$ (deformation mode of $\mathrm{O}-\mathrm{H}$ [ribose] and in plane deformation mode of $\mathrm{N}(3)-\mathrm{H}$ ), around $1250 \mathrm{~cm}^{-1}$ (ring stretching mode of $[\mathrm{N}(1)-\mathrm{C}(2)-\mathrm{N}(3)]$ and $\mathrm{C}-\mathrm{H}$ bending mode in uracil), $1050 \mathrm{~cm}^{-1}(\mathrm{C}-\mathrm{C}$ stretching mode in ribose, $\mathrm{C}-\mathrm{O}$ stretching mode in ribose, $\mathrm{N}(1)-\mathrm{C}\left(1^{\prime}\right)$ stretching mode), $970 \mathrm{~cm}^{-1}$ (symmetrical stretching mode of $\mathrm{PO}_{3}{ }^{2-}$ ), $900 \mathrm{~cm}^{-1}$ (C-C stretching mode in ribose), $800 \mathrm{~cm}^{-1}$ (P-O stretching mode, $\mathrm{C}-\mathrm{C}$ stretching mode in ribose and $\mathrm{C}-\mathrm{H}$ rocking mode in uracil), $750 \mathrm{~cm}^{-1}(\mathrm{C}-\mathrm{H}$ rocking mode in uracil and $\mathrm{C}=\mathrm{O}$ rocking mode) and $625 \mathrm{~cm}^{-1}$ ( $\mathrm{C}-\mathrm{C}-\mathrm{O}$ bending mode in ribose and $\mathrm{C}=\mathrm{O}$ bending mode).

After conditioning in water, for both types of hydrogels, the band at $1690 \mathrm{~cm}^{-1}$ becomes sharper at first, but from $8 \mathrm{~h}$ of conditioning it is less intense and moves towards lower frequencies. After a sufficiently long time $(72 \mathrm{~h})$, it appears at a wavenumber similar to that in the $\mathrm{CH}$ spectrum. Additionally, a peak appears at $1586 \mathrm{~cm}^{-1}$ for both systems after $72 \mathrm{~h}$. On the other hand, the band at $1475 \mathrm{~cm}^{-1}$ is present but with a little more intensity. After conditioning in water, the next two peaks at 1437 and $1390 \mathrm{~cm}^{-1}$ move towards lower wavenumbers and appear at 1420 and $1375 \mathrm{~cm}^{-1}$, respectively, as for the $\mathrm{CH}$ molecule. In the case of the band around $1250 \mathrm{~cm}^{-1}$, intensity decreases for both types of biomaterials conditioned for longer than $8 \mathrm{~h}$.

In the range of wavenumbers $1200-800 \mathrm{~cm}^{-1}$, in the spectrum of the CH/LA/UMP system from $8 \mathrm{~h}$ of conditioning, and the $\mathrm{CH} / \mathrm{HCL} / \mathrm{UMP}$ system from $24 \mathrm{~h}$, bands appear at 1151 and $1020 \mathrm{~cm}^{-1}$; they are characteristic of the saccharide structure. The peaks at the frequencies of 1050 and $970 \mathrm{~cm}^{-1}$, along with the extension of the conditioning time, are less intense for both systems and shift towards higher wavelengths: 1060 and $988 \mathrm{~cm}^{-1}$, respectively, as in the spectrum of pure chitosan. Moreover, in the spectra of both types of hydrogels conditioned in water, the band at $900 \mathrm{~cm}^{-1}$ does not have significant changes.

In turn, the bands at 800 and $750 \mathrm{~cm}^{-1}$ are clearly visible up to a defined time (24 h) and then they disappear leaving trace amounts. The peak at $625 \mathrm{~cm}^{-1}$, in the spectra of the $\mathrm{CH} / \mathrm{LA} / \mathrm{UMP}$ and the $\mathrm{CH} / \mathrm{HCL} / \mathrm{UMP}$ systems, moves towards a higher wavenumber $\left(664 \mathrm{~cm}^{-1}\right)$.

Interpretation of the FTIR spectra was based on previous studies [50-52].

\subsection{Crystallinity-XRD Diffractograms}

The structural changes of the hydrogels were defined based on powder X-ray diffraction analysis (XRD).

The diffraction patterns of the $\mathrm{CH} / \mathrm{LA} / \beta$-GP and the $\mathrm{CH} / \mathrm{HCL} / \beta$-GP systems after conditioning in water are shown in Figures 9 and 10.

In turn, Figures 11 and 12 present the diffraction patterns of chitosan lactate hydrogels (the $\mathrm{CH} / \mathrm{LA} / \mathrm{UMP}$ system) and chitosan chloride (the $\mathrm{CH} / \mathrm{HCL} / \mathrm{UMP}$ system) with uridine $5^{\prime}$-monophosphate disodium salt. 


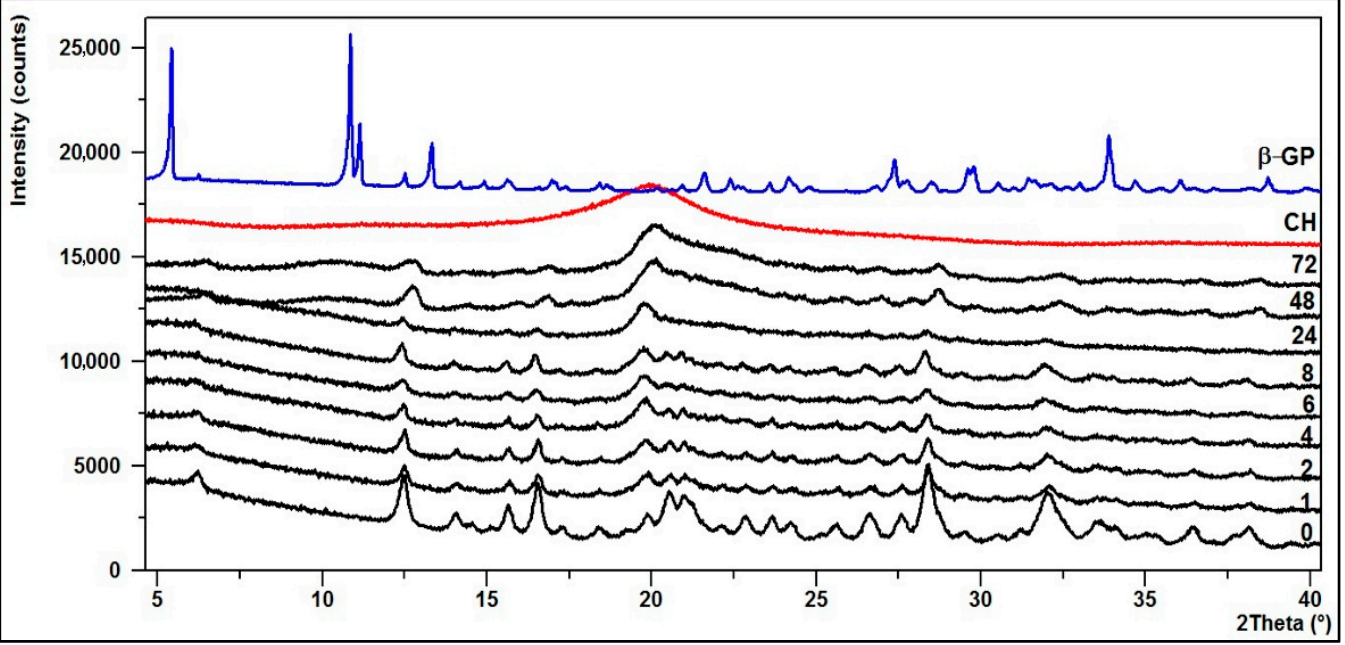

Figure 9. XRD diffraction patterns of the $\mathrm{CH} / \mathrm{LA} / \beta-\mathrm{GP}$ system conditioned in water.

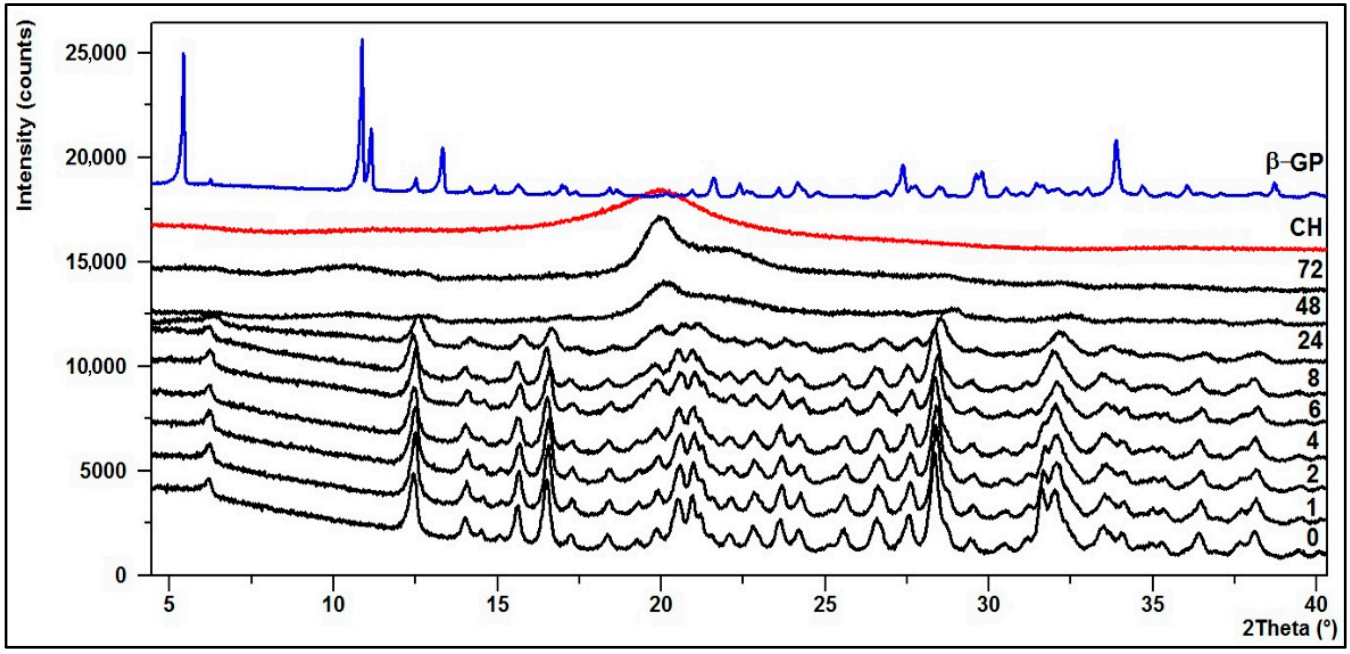

Figure 10. XRD diffraction patterns of the $\mathrm{CH} / \mathrm{HCL} / \beta-\mathrm{GP}$ system conditioned in water.

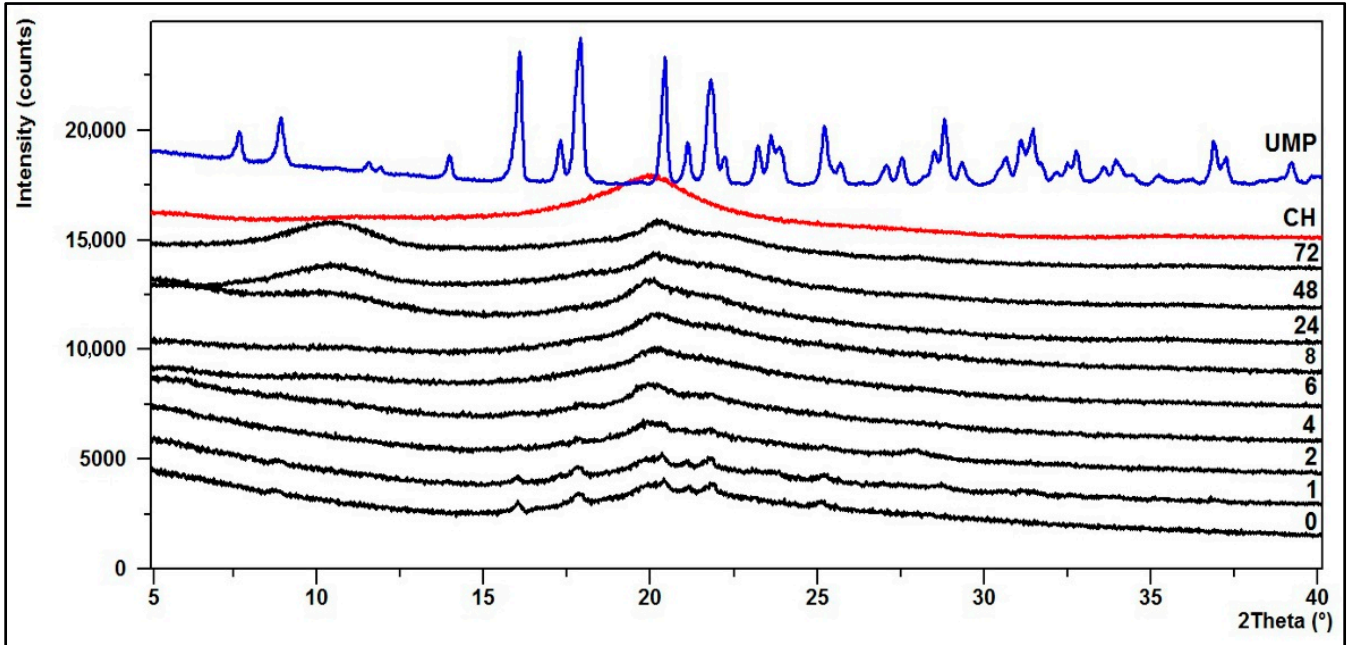

Figure 11. XRD diffraction patterns of the $\mathrm{CH} / \mathrm{LA} / \mathrm{UMP}$ system conditioned in water. 


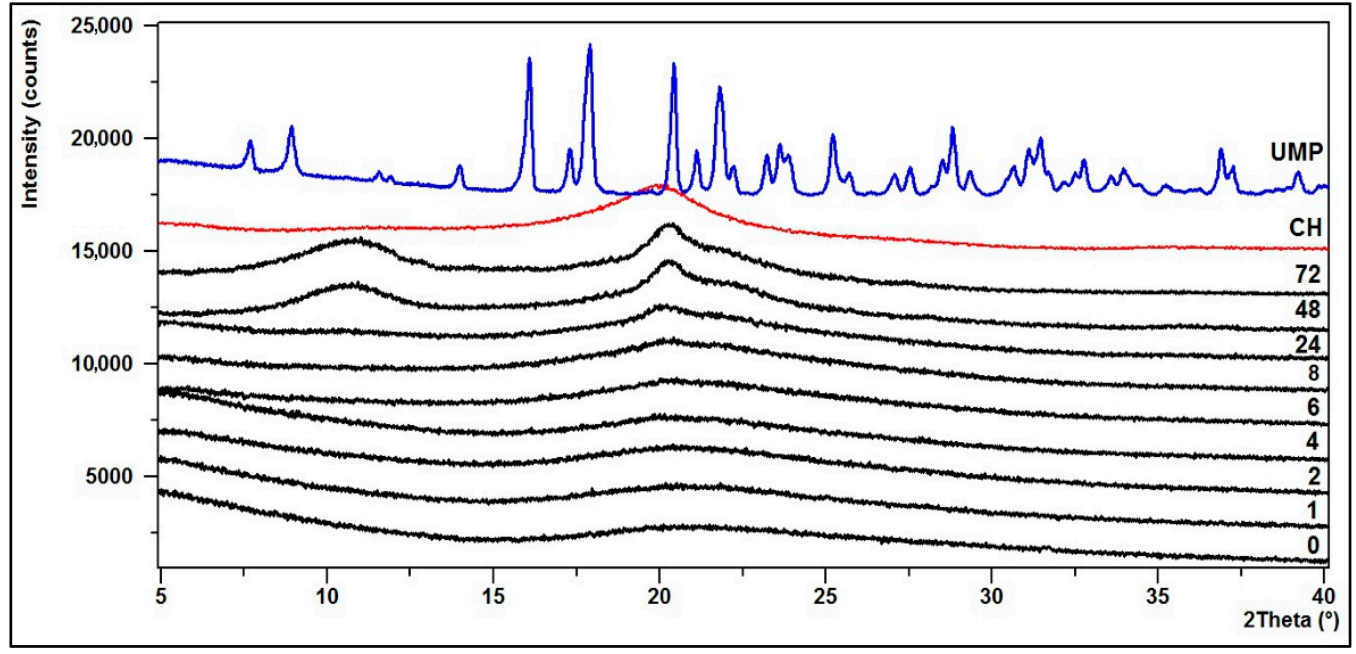

Figure 12. XRD diffraction patterns of the $\mathrm{CH} / \mathrm{HCL} / \mathrm{UMP}$ system conditioned in water.

The XRD pattern of the starting polymer $(\mathrm{CH})$ is characterized by a typical reflex at $2 \theta \approx 20^{\circ}$, which indicates that chitosan as a polymer with low crystallinity index is a rather amorphous body [53].

Upon the transformation of chitosan into thermosensitive hydrogels, its structure changes. The diffractogram of the $\mathrm{CH} / \mathrm{LA} / \beta$-GP system $(0 \mathrm{~min})$ shows that the hydrogel is partially crystalline and characterized by a number of small bands and five distinct peaks with maxima at $2 \theta$ angles of about $12,17,20,28$ and $32^{\circ}$. Similar features are visible on the diffractogram of the $\mathrm{CH} / \mathrm{HCL} / \beta-\mathrm{GP}$ system $(0 \mathrm{~min})$, but in this case the peaks are more intense and stronger. This is indicative of a structure with a higher crystallinity due to the formation of a compound between glycerophosphate and chitosan or precipitation of sodium chloride, which appeared after drying.

In the case of hydrogels conditioned in water for up to 8 (the $\mathrm{CH} / \mathrm{LA} / \beta$-GP system) or $24 \mathrm{~h}$ (the $\mathrm{CH} / \mathrm{HCL} / \beta$-GP system), their structure does not significantly change although the intensity of the peaks decreases. However, after longer conditioning, due to the leaching of sodium glycerophosphate, the structure of gels returns to pure chitosan.

The diffractogram of the CH/LA/UMP system $(0 \mathrm{~min})$ shows that the hydrogel is partially crystalline and characterized by six peaks at the angles of $2 \theta=16,18,20.5,21,22$ and $25^{\circ}$. In the case of the hydrogel conditioned in water for up to $4 \mathrm{~h}$, the intensity of the above peaks decreases. After $6 \mathrm{~h}$, the XRD pattern starts to resemble the diffractogram of a pure polymer. From $48 \mathrm{~h}$ of conditioning, two bands at the angles of $2 \theta \approx 11$ and $20^{\circ}$, characteristic for the $\mathrm{CH}$ molecule, are clearly visible.

On the other hand, the diffractogram for the $\mathrm{CH} / \mathrm{HCL} / \mathrm{UMP}$ system $(0 \mathrm{~min})$ shows that the biomaterial is practically amorphous. From $24 \mathrm{~h}$ of conditioning in water, the structure of the hydrogel returns to pure polymer and from $48 \mathrm{~h}$, two typical peaks at angles of $2 \theta \approx 11$ and $20^{\circ}$ are noticeable.

The presented diffractograms confirm the suggestions resulting from the analysis of FTIR spectra.

\subsection{Analysis of the Cytotoxicity of Chitosan Hydrogels}

Although chitosan hydrogels crosslinked by $\beta$-GP are highly studied in biomedical research, no information is available as to the biocompatibility of systems with UMP. Therefore, the safety profile of both types of gels was compared in the present work.

The resazurin assay, a quantitative and rapid colorimetric method, was chosen to preliminarily screen the cytotoxicity range of the $\mathrm{CH} / \mathrm{LA} / \beta-\mathrm{GP}, \mathrm{CH} / \mathrm{HCL} / \beta-\mathrm{GP}, \mathrm{CH} / \mathrm{LA} / \mathrm{UMP}$ and $\mathrm{CH} / \mathrm{HCL} / \mathrm{UMP}$ systems. This method is based on the reduction of oxidized nonfluorescent blue resazurin to a pink, fluorescent dye (resorufin) by cell activity (likely by oxygen consumption through metabolism) [54,55]. 
The results shown in Figure 13 summarize the viability of HT-29 cells incubated with the hydrogels for $48 \mathrm{~h}$.

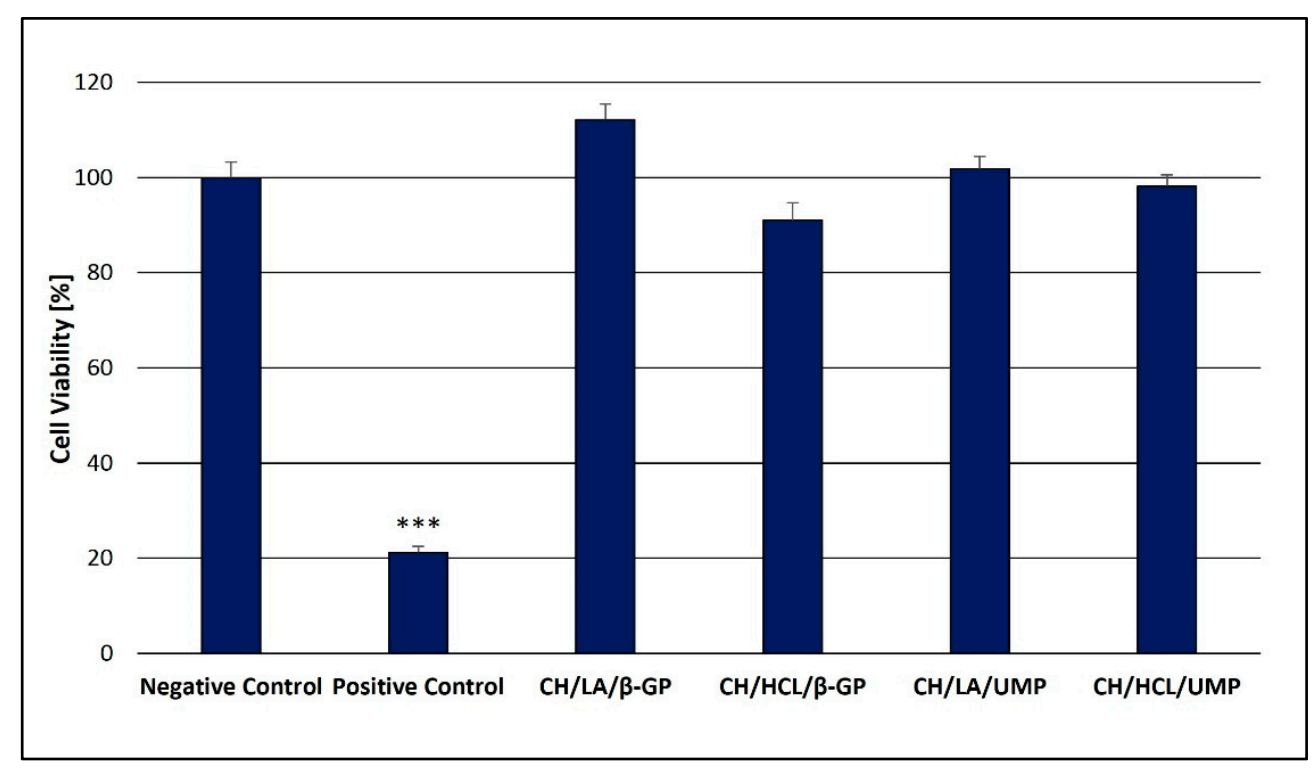

Figure 13. Cytotoxicity of the chitosan hydrogels. ${ }^{* *} p<0.001$ versus negative control.

The studies on cytotoxicity revealed that in the case of all the tested hydrogels, irrespective of the solvent and crosslinking agent used, no negative impact on human colon adenocarcinoma cells (HT-29) was observed.

In the case of chitosan lactate gels (the $\mathrm{CH} / \mathrm{LA} / \beta$-GP and the $\mathrm{CH} / \mathrm{LA} / \mathrm{UMP}$ systems), increased cell proliferation in relation to the negative control is observed (median of cell viability: 112.1 and $101.8 \%$ respectively). Slightly higher cytotoxic response is noticed for biomaterials prepared from chitosan chloride (the CH/HCL/ $\beta-\mathrm{GP}$ and the CH/HCL/UMP systems) - the median of cell viability is 91.0 and $98.2 \%$, respectively - which is probably due to the fact that hydrochloric acid has a lower $\mathrm{pH}(\mathrm{pH}<1)$ than lactic acid $(\mathrm{pH} 2.44)$.

\subsection{Evaluation of Genotoxicity of Chitosan Hydrogels}

Apart from cytotoxicity assessment, the evaluation of genotoxicity is another factor determining the use of biomaterials in medicine. The advantage of in vitro studies on biocompatibility is that multiple samples can be evaluated simultaneously. Moreover, only the materials that appear to be effective can be further analyzed in vivo in experimental models. The use of cell culture assays allows for a quick and easy examination of cellular processes using small amounts of the tested substance, and their great advantage is repeatability. These tests are ethically more acceptable in comparison to in vivo animal experiments and, more importantly, their results may lead to significant clinical conclusions in biomaterial research [56].

In this study, a genotoxicity assessment of the chitosan hydrogels was performed using the alkaline version of the comet assay. This technique is a highly specific, sensitive, and rapid method, which enables the detection of oxidative DNA damage, single- and double-stranded breaks as well as the presence of alkaline labile sites. The first versions of the test were developed in 1978 by Rydberg and Johanson, who described the detection of single-strand DNA breaks in individual cells embedded in agarose $[57,58]$.

The amount of DNA damage was assessed based on the percentage of DNA in the comet tail (Figures 14 and 15). 


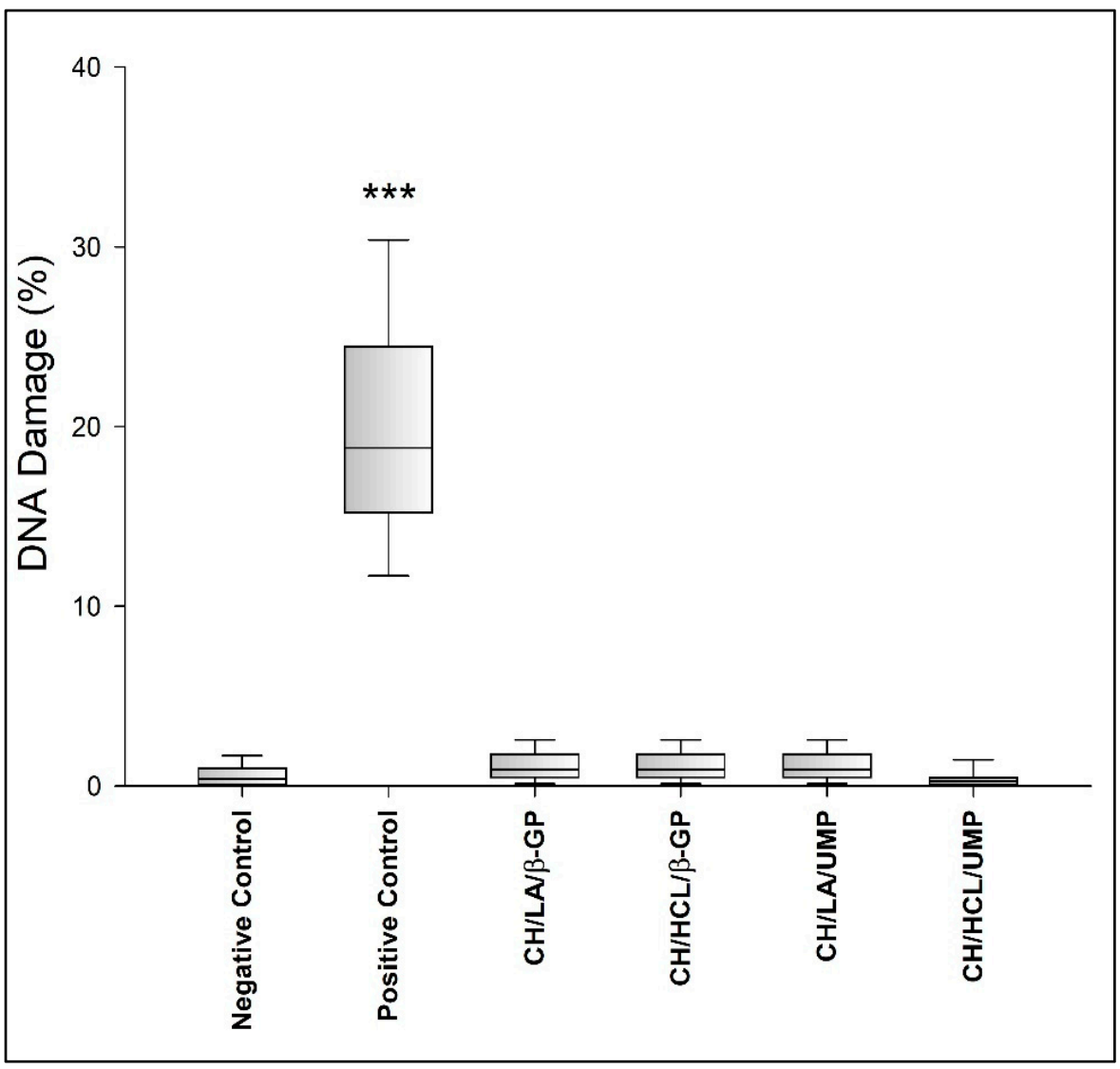

Figure 14. Genotoxicity of the chitosan hydrogels. ${ }^{* * *} p<0.001$ versus negative control.
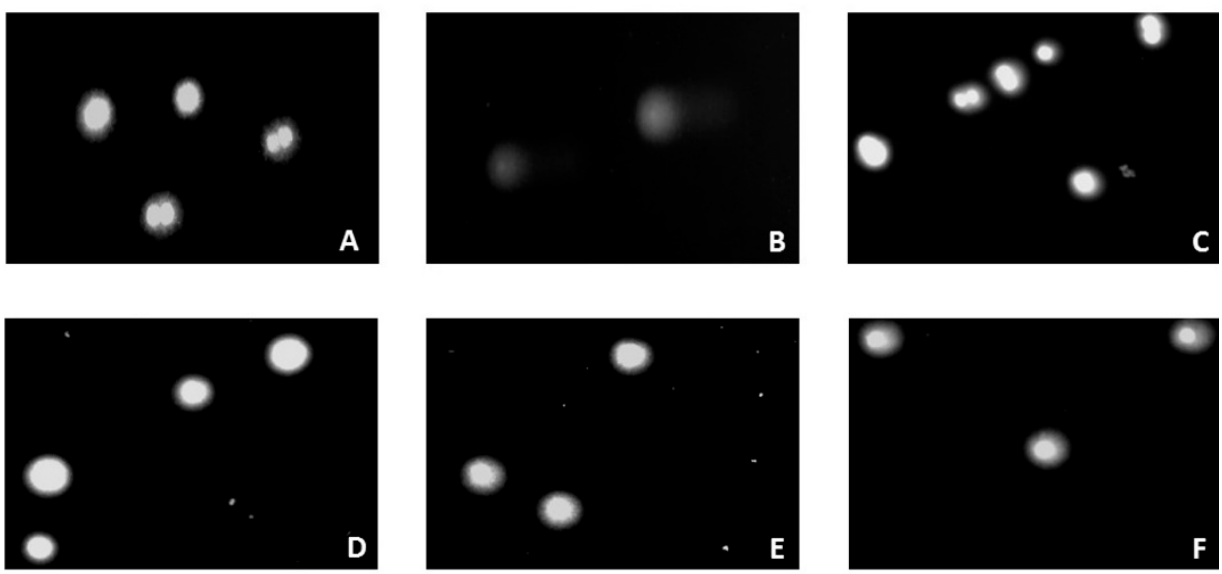

Figure 15. Representative images (200 $\times$ magnification) of the comet assay in HT-29 cells after $48 \mathrm{~h}$ of exposure: (A) negative control, (B) positive control, (C) CH/LA/ $\beta$-GP treated, (D) CH/HCL/ $\beta$-GP treated, (E) $\mathrm{CH} / \mathrm{LA} / \mathrm{UMP}$ treated, $(\mathrm{F}) \mathrm{CH} / \mathrm{HCL} / \mathrm{UMP}$ treated.

The obtained results show that all tested variants of chitosan hydrogels, irrespective of the solvent and crosslinking agent used, do not induce significant DNA damage in HT-29 cells (all systems give $<2 \%$ DNA damage). As depicted in Figure 15, cells exposed to chitosan hydrogels predominantly display a round-shaped head, which is part of the undamaged DNA without visible tail (fragmented DNA) similar to the negative control cells (A), indicating that the hydrogels and their components do not induce a genotoxic effect in human colon adenocarcinoma cells.

The findings of the biological study suggested that all the analyzed chitosan hydrogels could be candidates for scaffolds with good biocompatibility. However, due to the fact that 
the potential area of application of the developed biomaterials, in particular the hydrogels containing UMP, is neural tissue engineering, further studies using, for example, the astrocyte cell line (C8-D1A line), should be carried out.

\section{Conclusions}

This study demonstrates the thermosensitive chitosan lactate and chitosan chloride hydrogels. The biomaterials were prepared via sol-gel technique with the use of two crosslinking agents ( $\beta$-glycerol phosphate disodium salt pentahydrate ( $\beta$-GP) and uridine $5^{\prime}$-monophosphate disodium salt (UMP)).

Based on structural studies, it was found that the structure of all analyzed hydrogels changed due to conditioning in water. Changes in FTIR spectra of hydrogels with $\beta$-GP can be observed in the range of the broad band $3600-3100 \mathrm{~cm}^{-1}$, but mainly in the range of the amide band $1680-1500 \mathrm{~cm}^{-1}$, band $1500-1200 \mathrm{~cm}^{-1}$ and band $1200-800 \mathrm{~cm}^{-1}$, which reflects the saccharide structure and is connected with the presence of phosphate ions. In the case of biomaterials with UMP, the most significant changes are recorded in the frequency range of $1750-600 \mathrm{~cm}^{-1}$. Regardless of the solvent and type of crosslinking agent used, conditioning of the hydrogels in water leads to FTIR spectra corresponding to the spectrum of the pure polymer. The analysis of spectra showed that the biomaterials containing UMP are characterized by faster release of the crosslinking agent than the gels with $\beta$-GP. Thus, the advantage of UMP could be its presence for delivering it in a possible neuronal growth procedure, which requires additional studies to be performed on the retention/release of UMP from the gel in the future. The obtained results of the analysis carried out with the room temperature powder X-ray diffraction technique confirm the general conclusions resulting from the FTIR spectra.

Since the anticipated field of application of the manufactured hydrogels is biomedicine, a crucial factor is their safety for the human body. Therefore, an important step was to assess the biocompatibility of the hydrogels in contact with the human colon adenocarcinoma cell line. Biological studies showed that biomaterials are non-cytotoxic and non-genotoxic, and the chitosan lactate gels (the $\mathrm{CH} / \mathrm{LA} / \beta$-GP and the $\mathrm{CH} / \mathrm{LA} / \mathrm{UMP}$ systems) even increase the cell proliferation in relation to the negative control.

Thus, the obtained hydrogels can be proposed as scaffolds for potential application in the clinical and tissue engineering field, being a promising tool in tissue-constructs development, for example nervous tissue, due to the application of the pyrimidine ribonucleotide (UMP), which has a regenerative effect on the components of the nervous system by improving neurotransmission.

\section{Patents}

Majsterek I., Modrzejewska Z., Pieklarz K., Tylman M.; Method for producing chitosan gels forming in the human body temperature, intended for injection scaffolds for breeding of nerve cells. Lodz University of Technology, Lodz. Poland. Patent application 235369. Publ. 29.06.2020 WUP.

Author Contributions: Conceptualization, Z.M., K.P., M.T. and I.M.; methodology, K.P., Z.M., M.T., W.M., I.M. and G.G.; formal analysis, K.P., G.G. and I.M.; investigation, K.P., Z.M., M.T., W.M. and G.G.; resources, Z.M., K.P., E.K., I.M. and W.M.; writing-original draft preparation, K.P. and G.G.; writing-review and editing, Z.M. and I.M.; visualization, K.P., M.T., W.M. and G.G.; supervision, Z.M. and I.M.; project administration, Z.M. and I.M.; funding acquisition, Z.M., K.P., E.K. and I.M. All authors have read and agreed to the published version of the manuscript.

Funding: This research was supported by a grant from the Young Scientists Fund at the Faculty of Process and Environmental Engineering at the Lodz University of Technology, Poland no. 501/10-342-7058, and the funds of the Medical University of Lodz.

Institutional Review Board Statement: Not applicable.

Informed Consent Statement: Not applicable. 
Data Availability Statement: Data sharing is not applicable to this article.

Conflicts of Interest: The authors declare no conflict of interest. The funders had no role in the design of the study; in the collection, analyses, or interpretation of data; in the writing of the manuscript, or in the decision to publish the results.

\section{References}

1. Castells-Sala, C.; Alemany-Ribes, M.; Fernández-Muiños, T.; Recha-Sancho, L.; López-Chicón, P.; Aloy-Reverté, C.; CaballeroCamino, J.; Márquez-Gil, A.; Semino, C.E. Current applications of tissue engineering in biomedicine. J. Biochips Tissue Chips 2013, S2, 1 .

2. Sharma, P.; Kumar, P.; Sharma, R.; Bhatt, V.D.; Dhot, P.S. Tissue Engineering; Current Status \& Futuristic Scope. J. Med. Life 2019, 12, 225-229. [CrossRef]

3. Howard, D.; Buttery, L.D.; Shakesheff, K.M.; Roberts, S.J. Tissue engineering: Strategies, stem cells and scaffolds. J. Anat. 2008, 213, 66-72. [CrossRef] [PubMed]

4. Kruk, A.; Gadomska-Gajadhur, A.; Sebai, A.; Ruśkowski, P. Rusztowania komórkowe w inżynierii tkankowej. Wyroby Medyczne 2017, 4, 31-35.

5. Błażewicz, M. Materiały dla inżynierii tkankowej. Inżynieria Biomateriałów 2001, 4, 32-35.

6. Deluzio, T.G.; Seifu, D.G.; Mequanint, K. 3D scaffolds in tissue engineering and regenerative medicine: Beyond structural templates? Pharm. Bioprocess. 2013, 1, 267-281. [CrossRef]

7. Kumar, R.; Griffin, M.; Butler, P. A Review of Current Regenerative Medicine Strategies that Utilize Nanotechnology to Treat Cartilage Damage. Open Orthop. J. 2016, 10, 862-876. [CrossRef] [PubMed]

8. Grolik, M. Inżynieria tkankowa-Nowe narzędzie w rekonstrukcji tkanek. Zeszyty Naukowe Towarzystwa Doktorantów Uniwersytetu Jagiellońskiego. Nauki Ścisłe 2011, 3, 33-41.

9. Asadian, M.; Chan, K.V.; Norouzi, M.; Grande, S.; Cools, P.; Morent, R.; De Geyter, N. Fabrication and Plasma Modification of Nanofibrous Tissue Engineering Scaffolds. Nanomaterials 2020, 10, 119. [CrossRef] [PubMed]

10. Slaughter, B.V.; Khurshid, S.S.; Fisher, O.Z.; Khademhosseini, A.; Peppas, N.A. Hydrogels in Regenerative Medicine. Adv. Mater. 2009, 21, 3307-3329. [CrossRef] [PubMed]

11. Berger, J.; Reist, M.; Mayer, J.; Felt, O.; Peppas, N.; Gurny, R. Structure and interactions in covalently and ionically crosslinked chitosan hydrogels for biomedical applications. Eur. J. Pharm. Biopharm. 2004, 57, 19-34. [CrossRef]

12. Ahn, S.-K.; Kasi, R.M.; Kim, S.-C.; Sharma, N.; Zhou, Y. Stimuli-responsive polymer gels. Soft Matter 2008, 4, 1151-1157. [CrossRef]

13. Hu, W.; Wang, Z.; Xiao, Y.; Zhang, S.; Wang, J. Advances in crosslinking strategies of biomedical hydrogels. Biomater. Sci. 2019, 7, 843-855. [CrossRef]

14. Liu, M.; Zeng, X.; Ma, C.; Yi, H.; Ali, Z.; Mou, X.; Li, S.; Deng, Y.; He, N. Injectable hydrogels for cartilage and bone tissue engineering. Bone Res. 2017, 5, 17014. [CrossRef]

15. Garg, S.; Garg, A. Hydrogel: Classification, Properties, Preparation and Technical Features. Asian J. Biomater. Res. 2016, 2, 163-170.

16. Dutta, S.D.; Patel, D.K.; Lim, K.-T. Functional cellulose-based hydrogels as extracellular matrices for tissue engineering. J. Biol. Eng. 2019, 13, 1-19. [CrossRef]

17. Peppas, N.A.; Hilt, J.Z.; Khademhosseini, A.; Langer, R. Hydrogels in Biology and Medicine: From Molecular Principles to Bionanotechnology. Adv. Mater. 2006, 18, 1345-1360. [CrossRef]

18. Anamica; Pande, P.P. Polymer Hydrogels and Their Applications. Int. J. Mater. Sci. 2017, 12, 11-14.

19. Pal, K.; Banthia, A.K.; Majumdar, D.K. Polymeric Hydrogels: Characterization and Biomedical Applications. Des. Monomers Polym. 2009, 12, 197-220. [CrossRef]

20. Huang, H.; Qi, X.; Chen, Y.; Wu, Z. Thermo-sensitive hydrogels for delivering biotherapeutic molecules: A review. Saudi Pharm. J. 2019, 27, 990-999. [CrossRef]

21. Grassi, G.; Farra, R.; Caliceti, P.; Guarnieri, G.; Salmaso, S.; Carenza, M.; Grassi, M. Temperature-Sensitive Hydrogels. Am. J. Drug Deliv. 2005, 3, 239-251. [CrossRef]

22. Pankongadisak, P.; Suwantong, O. The potential use of thermosensitive chitosan/silk sericin hydrogels loaded with longan seed extract for bone tissue engineering. RSC Adv. 2018, 8, 40219-40231. [CrossRef]

23. Yang, T.-T.; Cheng, Y.-Z.; Qin, M.; Wang, Y.-H.; Yu, H.-L.; Wang, A.-L.; Zhang, W.-F. Thermosensitive Chitosan Hydrogels Containing Polymeric Microspheres for Vaginal Drug Delivery. BioMed Res. Int. 2017, 2017, 1-12. [CrossRef] [PubMed]

24. Gong, C.; Qi, T.; Wei, X.; Qu, Y.; Wu, Q.; Luo, F.; Qian, Z. Thermosensitive Polymeric Hydrogels as Drug Delivery Systems. Curr. Med. Chem. 2012, 20, 79-94. [CrossRef]

25. Pokhrel, S.; Yadav, P.N.; Adhikari, R. Applications of Chitin and Chitosan in Industry and Medical Science: A Review. Nepal J. Sci. Technol. 2016, 16, 99-104. [CrossRef]

26. Kumar, M.N.V.R. A review of chitin and chitosan applications. React. Funct. Polym. 2000, 46, 1-27. [CrossRef]

27. Kurita, K. Chitin and Chitosan: Functional Biopolymers from Marine Crustaceans. Mar. Biotechnol. 2006, 8, 203-226. [CrossRef]

28. Rinaudo, M. Chitin and chitosan: Properties and applications. Prog. Polym. Sci. 2006, 31, 603-632. [CrossRef]

29. Kean, T.; Thanou, M. Biodegradation, biodistribution and toxicity of chitosan. Adv. Drug Deliv. Rev. 2010, 62, 3-11. [CrossRef]

30. Muzzarelli, R.A.A. Human enzymatic activities related to the therapeutic administration of chitin derivatives. Cell. Mol. Life Sci. 1997, 53, 131-140. [CrossRef] 
31. Vårum, K.M.; Myhr, M.M.; Hjerde, R.J.; Smidsrød, O. In vitro degradation rates of partially N-acetylated chitosans in human serum. Carbohydr. Res. 1997, 299, 99-101. [CrossRef]

32. Gorzelanny, C.; Pöppelmann, B.; Pappelbaum, K.; Moerschbacher, B.M.; Schneider, S.W. Human macrophage activation triggered by chitotriosidase-mediated chitin and chitosan degradation. Biomaterials 2010, 31, 8556-8563. [CrossRef]

33. Baldrick, P. The safety of chitosan as a pharmaceutical excipient. Regul. Toxicol. Pharmacol. 2010, 56, 290-299. [CrossRef]

34. Minami, S.; Suzuki, H.; Okamoto, Y.; Fujinaga, T.; Shigemasa, Y. Chitin and chitosan activate complement via the alternative pathway. Carbohydr. Polym. 1998, 36, 151-155. [CrossRef]

35. Dobolyi, A.; Juhász, G.; Kovacs, Z.; Kardos, J. Uridine function in the central nervous system. Curr. Top. Med. Chem. 2011, 11, 1058-1067. [CrossRef] [PubMed]

36. Negrão, L.; Almeida, P.; Alcino, S.; Duro, H.; Libório, T.; Silva, U.M.; Figueira, R.; Gonçalves, S.; Parra, L.N. Effect of the combination of uridine nucleotides, folic acid and vitamin B12 on the clinical expression of peripheral neuropathies. Pain Manag. 2014, 4, 191-196. [CrossRef] [PubMed]

37. Kim, M.S.; Park, S.J.; Chun, H.J.; Kim, C.-H. Thermosensitive Hydrogels for Tissue Engineering. J. Tissue Eng. Regen. Med. 2011, 8 , 117-123.

38. Zhou, H.Y.; Jiang, L.J.; Cao, P.P.; Li, J.B.; Chen, X.G. Glycerophosphate-based chitosan thermosensitive hydrogels and their biomedical applications. Carbohydr. Polym. 2015, 117, 524-536. [CrossRef]

39. Dessì, M.; Borzacchiello, A.; Mohamed, T.H.A.; Abdel-Fattah, W.I.; Ambrosio, L. Novel biomimetic thermosensitive $\beta$-tricalcium phosphate/chitosan-based hydrogels for bone tissue engineering. J. Biomed. Mater. Res. Part A 2013, 101, 2984-2993. [CrossRef]

40. Niranjan, R.; Koushik, C.; Saravanan, S.; Moorthi, A.; Vairamani, M.; Selvamurugan, N. A novel injectable temperature-sensitive zinc doped chitosan/ $\beta$-glycerophosphate hydrogel for bone tissue engineering. Int. J. Biol. Macromol. 2013, 54, 24-29. [CrossRef]

41. Su, W.-T.; Chou, W.-L.; Chou, C.-M. Osteoblastic differentiation of stem cells from human exfoliated deciduous teeth induced by thermosensitive hydrogels with strontium phosphate. Mater. Sci. Eng. C 2015, 52, 46-53. [CrossRef] [PubMed]

42. Mikhailov, S.N.; Zakharova, A.N.; Drenichev, M.S.; Ershov, A.V.; Kasatkina, M.A.; Vladimirov, L.V.; Novikov, V.V.; Kildeeva, N.R. Crosslinking of Chitosan with Dialdehyde Derivatives of Nucleosides and Nucleotides. Mechanism and Comparison with Glutaraldehyde. Nucleosides Nucleotides Nucleic Acids 2016, 35, 114-129. [CrossRef]

43. Pieklarz, K.; Tylman, M.; Modrzejewska, Z. Preparation and characterization of a new generation of chitosan hydrogels containing pyrimidine ribonucleotides. Prog. Chem. Appl. Chitin Deriv. 2020, XXV, 192-200. [CrossRef]

44. Damiri, F.; Bachra, Y.; Bounacir, C.; Laaraibi, A.; Berrada, M. Synthesis and Characterization of Lyophilized Chitosan-Based Hydrogels Cross-Linked with Benzaldehyde for Controlled Drug Release. J. Chem. 2020, 2020, 1-10. [CrossRef]

45. Tamburaci, S.; Tihminlioglu, F. Novel poss reinforced chitosan composite membranes for guided bone tissue regeneration. $J$. Mater. Sci. Mater. Med. 2017, 29, 1. [CrossRef]

46. Staroszczyk, H.; Sztuka, K.; Wolska, J.; Wojtasz-Pajakk, A.; Kołodziejska, I. Interactions of fish gelatin and chitosan in uncrosslinked and crosslinked with EDC films: FT-IR study. Spectrochim. Acta Part A Mol. Biomol. Spectrosc. 2014, 117, 707-712. [CrossRef] [PubMed]

47. Cheng, T.; Hund, R.-D.; Aibibu, D.; Horakova, J.; Cherif, C. Pure Chitosan and Chitsoan/Chitosan Lactate Blended Nanofibres made by Single Step Electrospinning. Autex Res. J. 2013, 13, 128-133. [CrossRef]

48. Bajer, D.; Kaczmarek, H. Study of the Influence OV UV Radiation on Biodegradable Blends Based on Chitosan and Starch. Prog. Chem. Appl. Chitin Deriv. 2010, XV,17-24.

49. Tylman, M.; Pieklarz, K.; Owczarz, P.; Maniukiewicz, W.; Modrzejewska, Z. Structure of chitosan thermosensitive gels containing graphene oxide. J. Mol. Struct. 2018, 1161, 530-535. [CrossRef]

50. Carmona, P.; Molina, M.; Escobar, R. Conformation-sensitive infrared bands of uridine-5'-monophosphate. J. Mol. Struct. 1991, 243, 297-306. [CrossRef]

51. Muntean, C.M.; Bratu, I.; Tripon, C.; Nalpantidis, K.; Purcaru, M.A.P.; Deckert, V. Molecular Relaxation Processes in Nucleic Acids Components as Probed with Raman Spectroscopy. Rev. Chim. 2017, 68, 2471-2475. [CrossRef]

52. Singh, M.S.; Homendra, N.; Lonibala, R.K. Coordinating properties of uridine $5^{\prime}$-monophosphate with selected Ln3+ ions in ionic micellar media. BioMetals 2012, 25, 1235-1246. [CrossRef] [PubMed]

53. De Queiroz Antonino, R.; Lia Fook, B.; De Oliveira Lima, V.; De Farias Rached, R.; Lima, E.; Da Silva Lima, R.; Peniche Covas, C.; Lia Fook, M. Preparation and Characterization of Chitosan Obtained from Shells of Shrimp (Litopenaeus vannamei Boone). Mar. Drugs 2017, 15, 141. [CrossRef] [PubMed]

54. Al-Nasiry, S.; Geusens, N.; Hanssens, M.; Luyten, C.; Pijnenborg, R. The use of Alamar Blue assay for quantitative analysis of viability, migration and invasion of choriocarcinoma cells. Hum. Reprod. 2007, 22, 1304-1309. [CrossRef] [PubMed]

55. Borra, R.C.; Lotufo, M.A.; Gagioti, S.M.; Barros, F.D.M.; Andrade, P.M. A simple method to measure cell viability in proliferation and cytotoxicity assays. Braz. Oral Res. 2009, 23, 255-262. [CrossRef] [PubMed]

56. Williams, D.F. On the mechanisms of biocompatibility. Biomaterials 2008, 29, 2941-2953. [CrossRef] [PubMed]

57. Tice, R.R.; Agurell, E.; Anderson, D.; Burlinson, B.; Hartmann, A.; Kobayashi, H.; Miyamae, Y.; Rojas, E.; Ryu, J.C.; Sasaki, Y.F. Single cell gel/comet assay: Guidelines for in vitro and in vivo genetic toxicology testing. Environ. Mol. Mutagen. 2000, 35, 206-221. [CrossRef]

58. Vandghanooni, S.; Eskandani, M. Comet Assay: A Method to Evaluate Genotoxicity of Nano-Drug Delivery System. BioImpacts 2011, 1, 87-97. [PubMed] 